\title{
Pengaruh Gender Diversity Dewan, Ukuran Dewan Komisaris, Komisaris Independen, Komite Audit dan Konsentrasi Kepemilikan terhadap Agresivitas Pajak
}

\author{
Imora Kamul, Ernie Riswandari \\ Universitas Bunda Mulia \\ Imorakamul19@gmail.com,eriswandari@bundamulia.ac.id
}

\begin{abstract}
Tax aggressiveness is an action taken in order to reduce the burden of income tax by using legal (tax avoidance) and illegal (tax evasion) planning methods, which harm the government because it will reduce tax revenue. This study aims to obtain empirical evidence regarding the effect of board gender diversity, board of commissioners size, independent commissioners, audit committee and ownership concentration on tax aggressiveness. This study used the purposive sampling method and produced a final sample of 33 consumer goods sub-sector manufacturing companies listed on the Indonesia Stock Exchange for the 20172019 period. This study uses secondary data in the form of annual reports and company annual financial reports obtained from www.idx.co.id. The research analysis method used is the multiple regression analysis methods with a significance level of 5\%. Data processing was performed using SPSS version 26. The results showed that board gender diversity, independent commissioners, audit committee and ownership concentration had no significant effect on tax aggressiveness. Meanwhile, the size of the board of commissioners has a significant negative effect on tax. From the research results, it is concluded that the size of the board of commissioners is a driving factor for management's honesty in financial reporting so as to reduce tax aggressiveness.
\end{abstract}

Keywords: Board Gender Diversity; Board of Commissioners Size; Independent Commissioner; Audit Committee; Tax Aggressiveness

\begin{abstract}
Abstrak
Agresivitas pajak adalah sebuah tindakan yang dilakukan dalam rangka mengurangi beban pajak penghasilan dengan metode perencanaan legal (tax avoidance) maupun ilegal (tax evasion) yang di mana tentunya merugikan negara karena akan memperkecil penerimaan pajak negara. Penelitian ini bertujuan mendapatkan bukti empiris mengenai pengaruh gender diversity dewan, ukuran dewan komisaris, komisaris independen, komite audit dan konsentrasi kepemilikan terhadap agresivitas pajak. Penelitian ini menggunakan metode pengambilan sampel purposive sampling dan menghasilkan sampel akhir sebanyak 33 perusahaan manufaktur sub-sektor consumer goods yang terdaftar di Bursa Efek Indonesia Periode 2017-2019. Penelitian ini menggunakan data sekunder berupa laporan tahunan dan laporan keuangan tahunan perusahaan yang diperoleh dari
\end{abstract}


www.idx.co.id. Metode analisis penelitian yang digunakan adalah metode analisis regresi berganda dengan tingkat signifikansi sebesar 5\%. Pengolahan data dilakukan dengan SPSS versi 26. Hasil penelitian menunjukkan bahwa gender diversity dewan, komisaris independen, komite audit dan konsentrasi kepemilikan tidak berpengaruh signifikan terhadap agresivitas pajak. Sedangkan ukuran dewan komisaris berpengaruh signifikan negatif terhadap agresivitas pajak. Dari hasil penelitian, diperoleh kesimpulan bahwa ukuran dewan komisaris merupakan faktor pendorong kejujuran manajemen dalam pelaporan keuangan sehingga dapat mengurangi agresivitas pajak.

Kata kunci: Gender Diversity Dewan; Ukuran Dewan Komisaris; Komisaris Independen; Komite Audit; Agresivitas Pajak

\section{PENDAHULUAN}

Indonesia menerapkan Tax Amnesty berdasarkan pada UU No.11 Tahun 2016, di mana dilakukan pengampunan pajak atau penghapusan pajak yang harus dibayar dari harta yang tidak pernah dilaporkan selama ini. Program ini bertujuan untuk meningkatkan perolehan pajak negara. Hal tersebut telah menjadi usaha pemerintah meningkatkan penerimaan pajak, namun ternyata pada tahun 2017 menurut Badan Pusat Statistik penerimaan perpajakan mencapai Rp. 1.339,8 triliun atau 90,98\% dibandingkan tahun 2016 sebanyak 83,5\%.

Usaha-usaha yang dilakukan pemerintah Indonesia sudah cukup banyak untuk meningkatkan pendapatan pajak. Namun tetap ada perbedaan kepentingan antara wajib pajak dan pemerintah. Wajib pajak cenderung berkeinginan untuk meminimalisir beban pajak, sedangkan pemerintah cenderung ingin memperoleh penerimaan pajak sebanyak mungkin. Manajemen berperan penting dalam memilih strategi perusahaan khususnya untuk memperbanyak kekayaan perusahaan. Manajemen cenderung melakukan agresivitas pajak dalam usahanya untuk mengurangi beban pajak yang perlu dibayarkan (Harjito, Sari, \& Yulianto, 2017).

Tindakan agresivitas pajak yaitu langkah suatu perusahaan dalam mengecilkan penghasilan kena pajak dengan merencanakan pajak termasuk dengan cara tax evasion ataupun tax avoidance. Tindakan pajak agresif tidak hanya mengenai ketidakpatuhan terhadap aturan perpajakan, tetapi juga cara perusahaan menghemat pajak namun tetap berdasarkan pada peraturan perpajakan. Semakin besar celah atau grey area dimanfaatkan dari aturan perpajakan untuk menghemat beban pajak maka semakin tinggi tingkat agresivitas pajaknya walaupun tindakan tersebut masih sesuai dengan aturan yang ada, (Harnovinsah \& Mubarakah, 2016).

Pada penelitian ini, pengukuran agresivitas pajak dilakukan dengan Effective Tax Rate, karena saat perusahaan berusaha menghindari pajak dengan mengurangi laba kena pajak maka ETR menjadi rendah. Sedangkan perusahaan yang sedikit melakukan perencanaan pajak (tidak agresif) maka nilai ETR menjadi lebih tinggi.

* Corresponding author's e-mail: eriswandari@bundamulia.ac.id http://openjournal.unpam.ac.id/index.php/JABI 
Pada penelitian sebelumnya terdapat faktor-faktor yang mempengaruhi agresivitas pajak. Faktor-faktor yang berhubungan dengan agresivitas pajak antara lain gender diversity dewan, ukuran dewan komisaris, komisaris independen, komite audit dan konsentrasi kepemilikan.

Partisipasi wanita dalam dewan terhadap agresivitas pajak menjadi fokus peneliti karena adanya peraturan-peraturan di beberapa negara yang telah mewajibkan adanya anggota wanita dalam dewan. Sebagai contoh pemerintah Norwegia, India dan Spanyol memberikan mandat bahwa setiap dewan diharapkan terdapat anggota wanita, (Oyotode-Adebile \& Raja, 2019).

International Finance Corporation telah melakukan berbagai upaya untuk melibatkan wanita dalam dewan sejak tahun 2013, yaitu salah satunya dengan program Women on Board. Program ini berfokus pada pelatihan dan bimbingan untuk para wanita untuk memperkuat kemampuannya mencapai manajemen puncak, dan perusahaan memperoleh berbagai manfaat dengan adanya kesetaraan gender. IFC yakin bahwa wanita berperan penting dalam kesuksesan perusahaan.

Jika dikaitkan dengan pajak, terdapat beberapa penelitian sebelumnya yang sudah meneliti terkait keberadaan anggota dewan wanita atau gender diversity dengan agresivitas pajak. Menurut penelitian Ambarsari, Pratomom \& Kurnia (2019) dan Richardson, Taylor, \& Lanis (2016) gender diversity dewan memiliki pengaruh terhadap agresivitas pajak. Namun berdasarkan penelitian Oyenike, Olayinka, Emeni, \& Francis (2016) gender diversity tidak memiliki pengaruh signifikan terhadap agresivitas pajak. Padahal seharusnya dewan wanita berpengaruh pada agresivitas pajak karena semakin banyak anggota dewan wanita dalam dewan menyebabkan semakin tinggi ETR (menurunnya agresivitas pajak) sebab anggota dewan wanita memiliki kebiasaan untuk menghindari risiko tinggi dibanding pria sehingga bisa mempengaruhi keputusan financial dan hasil (Oyenike, Olayinka, Emeni, \& Francis, 2016). Namun dikarenakan proporsi wanita yang jauh lebih kecil dari pria dalam dewan, menyebabkan kurangnya keterwakilan dan kekurangan dewan wanita yang profesional di posisi senior atau manajemen puncak. Hal ini bisa menjadi alasan mengapa tidak berpengaruh antara anggota dewan wanita dengan agresivitas pajak (Oyenike, Olayinka, Emeni, \& Francis, 2016).

Dewan komisaris berkewajiban mengawasi kebijakan direksi dalam rangka mengelola perusahaan dan memberi arahan atau nasihat kepada direksi agar perusahaan berjalan secara efektif. Dewan komisaris lebih berfokus pada fungsi pengawasan dan penerapan kebijakan direksi. Peran penting dewan komisaris untuk menuntun strategi dan memperhatikan direksi termasuk di dalamnya terkait perencanaan pajak.

Menurut penelitian Richardson dan Lanis (2011) yang dijelaskan dalam penelitian Ratnawati, Wahyunir, \& Abduh (2019) menemukan bahwa jumlah anggota dewan komisaris secara signifikan mempunyai pengaruh terhadap agresivitas pajak. Annuar, Salihu dan Obid (2014) dalam Ratnawati, Wahyunir, \& Abduh (2019) juga menemukan komposisi dewan komisaris dapat mempengaruhi penghindaran pajak. Penelitian Ratnawati, Wahyunir, \& Abduh (2019) sendiri juga menemukan pengaruh signifikan negatif dari ukuran dewan komisaris dan agresivitas pajak. Penelitian Peter Rawlings Osebe (2019) juga menemukan 
hubungan signifikan positif antara ukuran dewan dengan Effective Tax Rate yang dapat diartikan berpengaruh negatif terhadap agresivitas pajak. Namun pada penelitian Ambarsari, Pratomo, \& Kurnia (2019) menjelaskan jika tidak terdapat pengaruh dalam hubungan ukuran dewan komisaris dengan agresivitas pajak.

Komisaris independen (independent commissioner) berperan sebagai kekuatan penyeimbang (conterveilling power) bagi dewan komisaris untuk pengambilan keputusan. Dewan komisaris ditentukan oleh pemegang saham sebagai perwakilan para pemegang saham pada Rapat Umum Pemegang Saham (RUPS) (Effendi, 2016). Jika dikaitkan dengan pajak, tentu saja komisaris independen berhak memberikan keputusan terkait laba secara komersial maupun laba secara pajak.

Menurut penelitian Rosidy \& Nugroho (2019) komisaris independen secara signifikan memiliki pengaruh positif terhadap agresivitas pajak. Menurut penelitian Fadli (2016) komisaris independen memiliki pengaruh signifikan negatif terhadap agresivitas pajak. Lain halnya menurut Arismajayanti \& Jati (2017) dan Dhamara \& Violita (2018), menemukan tidak adanya pengaruh antara komisaris independen dengan agresivitas pajak.

Mengingat komisaris tugasnya cukup berat dalam mengawasi jalannya perusahaan, maka ada beberapa komite yang membantu komisaris, salah satunya komite audit. Keberadaan komite audit bermanfaat dalam menjamin transparasi, keterbukaan laporan keuangan, keadilan bagi stakeholder, dan pengungkapan informasi yang dilakukan oleh manajemen (Nabilah dan Daljono, 2012) dalam (Oktavianna, 2021). Ikatan Komite Audit Indonesia (IKAI) mengartikan komite audit ialah sebuah komite yang bekerja dengan profesionalitas dan independensi, diciptakan oleh dewan komisaris, bertugas untuk mendukung dan mendorong fungsi pengawasan dari dewan komisaris terhadap pelaporan keuangan, pelaksanaan audit, manajemen risiko dan penerapan dari tata kelola di perusahaan (Effendi, 2016).

Jika dikaitkan dengan pajak tentunya komite audit memiliki keterkaitan dengan agresivitas pajak. Komite audit tugasnya mengawasi jalannya perusahaan. Sehingga ketika terjadi perencanaan pajak (agresivitas pajak), peran komite audit dalam hal tersebut cukup signifikan karena terkait jalannya perusahaan. Menurut teori keagenan (agency theory) peran komite audit yang mengawasi manajemen perusahaan akan lebih efektif dalam meminimalisir agresivitas pajak yang dilakukan manajemen (Arismajayanti \& Jati, 2017).

Menurut penelitian yang telah dilakukan peneliti sebelumnya, komite audit secara signifikan memiliki pengaruh negatif terhadap agresivitas pajak (Setu Setyawan, 2019). Namun penelitian Sri Ayem (2019) menemukan pengaruh signifikan positif. Sedangkan menurut Ratnawati, Wahyunir, \& Abduh (2019) komite audit tidak memiliki pengaruh signifikan terhadap agresivitas pajak.

Dugaan faktor lain yang mempengaruhi agresivitas pajak yaitu konsentrasi kepemilikan. Struktur kepemilikan saham dari suatu perusahaan terdiri atas komposisi kepemilikan dan konsentrasi kepemilikan. Peneliti akan lebih fokus pada konsentrasi kepemilikan. Konsentrasi kepemilikan muncul akibat perbedaan besarnya jumlah modal yang ditanam oleh investor. Konsentrasi kepemilikan adalah tingkat distribusi kepemilikan dari pemegang saham. Semakin tinggi 
konsentrasi kepemilikian artinya kepemilikan perusahaan lebih terpusat. Sedangkan semakin rendah konsentrasi kepemilikan artinya kepemilikan perusahaan tersebar di banyak pemegang saham. Pada sebuah penelitian di China, terdapat pengaruh positif antara konsentrasi kepemilikan dengan agresivitas pajak (Ying, Wright, \& Huang, 2017). Artinya makin tinggi konsentrasi kepemilikan menyebabkan perusahaan makin agresif dalam perencanaan pajak. Hal tersebut dapat terjadi karena pemegang saham mayoritas tersebut berharap laba yang dihasilkan tinggi maka akan berusaha mengecilkan pajak. Penelitian Ogbeide \& Obaretin (2018) dan Pratiwi \& Ardiyanto (2018) juga memperoleh hubungan signifikan positif antara konsentrasi kepemilikan dengan agresivitas pajak. Hasil penelitian Meita Fahrani (2018) menunjukkan hubungan antara konsentrasi kepemilikan dengan agresivitas pajak yang tidak signifikan.

Agresivitas pajak adalah kegiatan yang perlu diperhatikan di setiap perusahaan karena diharapkan tindakan perencanaan pajak tidak menjadi tindakan yang menyimpang dan melanggar hukum. Maka dari itu, peneliti ingin meneliti hubungan dari gender diversity, ukuran dewan komisaris, komisaris independen, komite audit dan konsentrasi kepemilikan terhadap agresivitas pajak.

Penulis melakukan penelitian ini bertujuan untuk mengetahui apakah gender diversity dewan, ukuran dewan komisaris , komisaris independen, komite audit dan konsentrasi kepemilikan berpengaruh terhadap agresivitas pajak.

Penelitian ini diharapkan dapat meningkatkan ilmu dan pengetahuan pada bidang akuntansi mengenai gender diversity dewan, ukuran dewan komisaris, komisaris independen, komite audit dan konsentrasi kepemilikan. Dan melalui penelitian ini dapat menambah referensi penelitian empiris yang membuktikan adanya agresivitas pajak yang dipengaruhi oleh gender diversity dewan, ukuran dewan komisaris, komisaris independen, komite audit dan konsentrasi kepemilikan.

Penelitian ini juga diharapkan berguna bagi pembuat kebijakan dan peraturan perpajakan, agar lebih mengidentifikasi dan memperhatikan perusahaan yang melakukan tindakan agresivitas pajak melalui gender diversity dewan, ukuran dewan komisaris, komisaris independen, komite audit dan konsentrasi kepemilikan sehingga penerimaan negara dapat dimaksimalkan. Dan untuk para investor, sebagai tambahan bahan evaluasi terkait penentuan keputusan untuk penanaman modal dan investasi, juga agar lebih berhati-hati sehingga terhindar dari resiko akibat dari tindakan agresivitas pajak pada laporan keuangan yang disusun oleh perusahaan.

\section{KERANGKA TEORITIS DAN PENGEMBANGAN HIPOTESIS}

Teori agensi Jensen dan Meckling (1976) dalam Rahayu, Ramadhanti, \& Widodo (2018) memiliki asumsi bahwa suatu entitas dipisahkan dari pemiliknya. Hubungan agensi merupakan hubungan antara satu atau lebih prinsipal (dalam hal ini pemegang saham) dengan agen (manajemen perusahaan) dalam pengambilan tindakan sesuai dengan kepentingan mereka termasuk pemberian otoritas dalam pengambilan keputusan oleh agen. Konflik agensi akan timbul ketika agen mengutamakan kepentingan pribadi dan tidak mengikuti keinginan dari prinsipal.

* Corresponding author's e-mail: eriswandari@bundamulia.ac.id 
Jurnal Akuntansi Berkelanjutan Indonesia - Vol. 4, No. 2, Mei 2021 - Kamul \& Riswandari

Pajak di Indonesia menerapkan sistem self-assessment yang dapat meningkatkan agresivitas pajak. Wajib pajak akan berusaha melakukan agresivitas pajak karena mereka sendiri yang mengetahui kondisi perusahaan secara detail. Sementara fiskus / otoritas pajak hanya pihak eksternal yang mengawasi tindakan perpajakan wajib pajak. Terdapat konflik agensi antara wajib pajak selaku agen, dan fiskus selaku prinsipal yaitu perbedaan kepentingan (Ratnawati, Wahyunir, \& Abduh, 2019). Wajib pajak ingin melakukan pembayaran pajak serendahrendahnya sedangkan fiskus ingin wajib pajak membayar pajak secara maksimal untuk kepentingan pendapatan pajak negara (Arismajayanti \& Jati, 2017).

Istilah gender dikenalkan oleh Robert Stoller (1968) pertama kali untuk memisahkan peran dan fungsi manusia berdasarkan pada pengartian karakteristik yang bersifat sosial budaya dengan berdasarkan pada ciri-ciri biologis. Ahimsa Putra dalam Utaminingsih (2017) menjelaskan bahwa pengertian gender dapat dibagi 2 yaitu: (1) gender adalah sebuah istilah asing dengan arti khusus, yang sulit untuk dipahami sehingga terjadi perbedaan dalam memandang gender, bahkan yang dipersamakan dengan perbedaan jenis kelamin; (2) gender adalah suatu peristiwa sosial budaya, jadi gender sebagai suatu kesadaran sosial yang dikonstruksikan oleh sosial budaya masyarakat. Mernissi dan Rifat menegaskan bahwa pria dan wanita sama atau setara walaupun dalam realitasnya masih belum sepenuhnya sama (Utaminingsih, 2017).

Agresivitas pajak ialah usaha untuk merekayasa penghasilan kena pajak dengan melakukan perencanaan pajak baik secara legal (tax avoidance) ataupun secara ilegal (tax evasion) (Pohan, 2016). Agresivitas pajak menurut Frank, Lynch dan Rego (2009) dalam Bani Alkausar (2020) juga dapat diartikan sebagai strategi untuk meminimalkan pajak dengan cara merencanakan pajak dengan cara legal maupun ilegal. Agresivitas pajak berpotensi mengancam pendapatan negara yang berasal dari pajak, karena fenomena yang terjadi tindakan agresivitas pajak umumnya lebih mengarah pada tindak ilegal perencanaan pajak yaitu tax evasion (Bani Alkausar, 2020). Harari et al. (2013) dalam Faridatul Makhfudloh (2018) menyebutkan bahwa praktik perencanaan agresivitas pajak dapat menghancurkan kemampuan masyarakat, kesetaraan sosial dirugikan dan pelaksanaan kebijakan sosial ekonomi terganggu dan menjadi beban bagi masyarakat yang tidak dapat melakukan perencanaan pajak.

Gender diversity dalam jajaran dewan telah banyak dibahas di seluruh dunia. Sebagai contoh, di Norwegia, India dan Spanyol pemerintahnya telah mewajibkan adanya anggota dewan wanita dalam komposisi dewan (Terjesen et al. (2009); Afsharipour (2015)) dalam (Oyotode-Adebile \& Raja, 2019). Di USA, The National Association of Corporate Directors Blue Ribbon Commission mensyaratkan gender diversity dalam dewan (Carter et al. dalam (Oyotode-Adebile \& Raja, 2019)).

Menurut Ambarsari, Pratomo \& Kurnia (2019) suatu perusahaan yang memiliki keberagaman gender dapat bermanfaat untuk meningkatkan pengetahuan, menemukan ide baru, dan tambahan pengetahuan atau pendapat dan pengalaman dalam membantu pemecahan masalah serta peningkatan dalam merencanakan strategis. Partisipasi yang lebih tinggi dari perempuan dalam dewan perusahaan umumnya dipromosikan karena anggota perempuan diyakini membawa informasi

* Corresponding author's e-mail: eriswandari@bundamulia.ac.id http://openjournal.unpam.ac.id/index.php/JABI 
dan pengetahuan penting kepada dewan karena pengalaman profesional yang lebih luas (Oyenike, Olayinka, Emeni, \& Francis, 2016).

Perbedaan perilaku menurut gender yaitu pria dan wanita dapat terlihat dari pengambilan keputusan yang dibuat oleh direktur yang cenderung berdampak pada keputusan strategis dan keuangan yang diambil. Perempuan cenderung lebih mematuhi persyaratan hukum dan tertarik pada masalah pajak saat mereka berada dalam jajaran. Wanita juga cenderung lebih berhati-hati dan menghindari risiko. (Oyenike, Olayinka, Emeni, \& Francis, 2016). Dewan wanita juga memiliki pemikiran yang lebih mandiri dan independen serta memfasilitasi pengambilan keputusan dengan lebih baik. Hal tersebut dapat meningkatkan transparansi dewan dan meningkatkan kepercayaan dari pemangku kepentingan kepada dewan (Richardson, Taylor, \& Lanis, 2016). Dengan sifat wanita yang cenderung menghindari resiko menyebabkan wanita lebih berhati-hati dalam perencanaan pajak. Sehingga jika ada kehadiran anggota dewan wanita memungkinkan untuk berkurangnya agresivitas pajak.

Menurut penelitian Ambarsari, Pratomo, \& Kurnia (2019), Richardson, Taylor, \& Lanis (2016) dan Oyenike, Olaynika, Emeni \& Francis (2016) keberadaan wanita dalam dewan atau keberagaman gender dewan memiliki pengaruh signifikan negatif terhadap agresivitas pajak. Maka dapat dikatakan jika terdapat wanita dalam dewan, dapat mengurangi agresivitas pajak dalam perusahaan. Oleh karena itu, peneliti akan merumuskan hipostesis berikut untuk penelitian ini:

\section{H1: Gender diversity dewan berpengaruh signifikan terhadap agresivitas pajak.}

Dewan komisaris terdiri dari komisaris independen dan non independen. Seluruh anggota dewan komisaris baik independen maupun non independen memiliki keterkaitan dengan pemegang saham, direktur dan komisaris lainnya dalam perusahaan tersebut. Menurut aturan GCG bahwa komisaris bertugas mengawasi kegiatan operasional perusahaan. Menurut Selviana (2010) dalam (Ratnawati, Wahyunir, \& Abduh, 2019) jika dewan komisaris tidak mengawasi dengan baik, dapat memunculkan kesempatan bagi manajemen untuk melakukan agresivitas pajak.

Menurut Inge Andhitya Ratnawati (2017) dewan komisaris bertugas mengawasi kebijakan perusahaan, memperhatikan kelengkapan dan kualitas informasi di laporan keuangan dan laporan kinerja direksi. Maka semakin besar ukuran dewan komisaris seharusnya semakin baik dalam monitoring perusahaan. Dengan banyaknya dewan komisaris menyebabkan perusahaan akan merasa lebih diperhatikan sehingga mengurangi kecurangan. Dengan tingginya pengawasan maka manajemen akan sulit dalam merencanakan pajaknya.

Penelitian Lanis dan Richardson (2011) dalam Ambarsari, Pratomo, \& Kurnia (2019) memperoleh hasil yaitu ukuran dewan komisaris berpengaruh signifikan terhadap agresivitas pajak. Hasil penelitian Ratnawati, Wahyunir, \& Abduh (2019) dan Peter Rawlings Osebe (2019) menemukan bahwa ukuran dewan komisaris secara signifikan memiliki pengaruh negatif terhadap agresivitas pajak. Oleh karena itu, peneliti melakukan perumusan hipotesis kedua sebagai berikut: 
Jurnal Akuntansi Berkelanjutan Indonesia - Vol. 4, No. 2, Mei 2021 - Kamul \& Riswandari

\section{H2: Ukuran dewan komisaris berpengaruh signifikan terhadap agresivitas pajak.}

Otoritas Jasa Keuangan mengeluarkan Peraturan No. 33/POJK.04/2014 mengenai Direksi dan Dewan Komisaris Emiten atau Perusahaan Publik pada Pasal 20 memaparkan bahwa dalam dewan komisaris paling sedikit terdiri atas 2 orang anggota dewan komisaris yang salah satunya adalah komisaris independen (Effendi, 2016).

Komisaris independen berperan penting dalam tata kelola perusahaan. Dari perspektif teori agensi, komisaris independen dapat mengurangi konflik dari agent dan principal dalam perusahaan yang diakibatkan oleh asimetris informasi. Komisaris independen yang mengawasi dengan ketat dapat menyebabkan manajemen menjadi lebih hati-hati dalam pembuatan keputusan dan lebih transparan dalam proses operasi perusahaan yang akhirnya dapat meminimalisir penghindaran pajak (Ardyansah and Zulaikha, 2014) dalam (Arismajayanti \& Jati, 2017).

Menurut penelitian Fadli (2016) komisaris independen memiliki pengaruh signifikan negatif terhadap agresivitas pajak. Artinya makin tinggi rasio komisaris independen dalam suatu perusahaan diharapkan dapat semakin kecil kecurangan yang dilakukan manajemen terkait pajak. Oleh karena itu, peneliti menerapkan perumusan hipotesis sebagai berikut:

\section{H3: Komisaris independen berpengaruh signifikan terhadap agresivitas pajak.}

Akibat dari beratnya tugas komisaris dalam pengawasan jalannya perusahaan, komisaris seharusnya didukung oleh beberapa komite, seperti komite audit. Ikatan Komite Audit Indonesia (IKAI) mengartikan komite audit sebagai sebuah komite yang diciptakan dewan komisaris, yang bekerja secara independen serta profesional dan, dengan tugasnya dalam mendorong dan membantu fungsi dewan komisaris untuk mengawasi manajemen risiko, proses pelaporan keuangan, penerapan tata kelola, serta pelaksanaan audit (Effendi, 2016).

Menurut penelitian Rachmitasari (2015) dalam Setu Setyawan (2019) menyebutkan bahwa mekanisme GCG dengan proksi komite audit berjalan dengan baik maka agresivitas pajak dalam perusahaan dapat ditekan. Karena tugas komite audit mengawasi, maka celah perusahaan melakukan perencanaan pajak akan semakin sempit. Dengan proporsi komite audit yang tinggi, perusahaan akan lebih berhati-hati dalam melakukan segala aktivitas bisnisnya dan mengikuti aturan perpajakan yang berlaku (Setu Setyawan, 2019).

Makin tinggi proporsi komite audit, perusahaan dapat merasa semakin diawasi, sebab tugas komite audit yang independen dan memiliki fungsi pengawasan dalam perusahaan. Mekanisme yang ketat oleh komite audit dapat memperkecil celah untuk melakukan agresivitas pajak (Setu Setyawan, 2019). Penelitian Setu Setyawan (2019) memperoleh pengaruh signifikan negatif antara komite audit dan agresivitas pajak. Maka dari itu, peneliti merumuskan hipotesis sebagai berikut:

\section{H4: Komite audit berpengaruh signifikan terhadap agresivitas pajak.}


Struktur kepemilikan saham dari suatu perusahaan terdiri atas komposisi kepemilikan dan konsentrasi kepemilikan. Perbedaan dalam besaran modal yang ditanamkan oleh investor akan memunculkan konsentrasi kepemilikan. Konsentrasi kepemilikan adalah tingkat distribusi kepemilikan dari pemegang saham. Semakin rendah konsentrasi kepemilikan yang dimiliki perusahaan maka makin tersebarnya kepemilikan perusahaan ke banyak pemegang saham, namun jika konsentrasi kepemilikan tinggi artinya terpusatnya kepemilikan suatu perusahaan. (Pratiwi \& Ardiyanto, 2018).

Menurut penelitian Ying, Wright, \& Huang (2017), Pratiwi \& Ardiyanto (2018), dan Ogbeide \& Obaretin (2018) bahwa konsentrasi kepemilikan berpengaruh signifikan positif terhadap agresivitas pajak. Artinya makin tinggi atau makin terkonsentrasi kepemilikan suatu perusahaan maka akan makin tinggi agresivitas pajak. Hal itu dikarenakan semakin terkonsentrasi kepemilikan suatu perusahaan, artinya pemegang saham semakin tersentralisasi, dan pengambilan keputusan juga dilakukan oleh pemegang saham mayoritas tersebut sehingga terkait merencanakan pajak juga menjadi lebih cepat pengambilan keputusannya. Maka itu, peneliti ingin melakukan perumusan hipotesis:

H5: Konsentrasi kepemilikan berpengaruh signifikan terhadap agresivitas pajak.

\section{METODE RISET}

Penelitian ini menggunakan pendekatan kuantitatif dengan jenis data sekunder. Teknik pengumpulan data dengan metode dokumentasi yaitu dengan mengumpulkan data dari laporan keuangan dan annual report yang diperoleh melalui website Bursa Efek Indonesia. Pengolahan data dilakukan dengan aplikasi IBM SPSS 26 dengan metode analisis regresi linier berganda. Subjek dalam penelitian ini ialah perusahaan-perusahaan manufaktur sub sektor consumer goods yang telah terdaftar di Bursa Efek Indonesia (BEI) periode 2017-2019. Subjek ini dipilih sebagai novelty dan dikarenakan perusahaan barang konsumsi berkembang terus menerus karena produknya yang selalu dibutuhkan masyarakat, sehingga penghasilan akan terus meningkat dan pajak semakin tinggi sehingga makin mungkin terjadi perencanaan pajak. Variabel yang menjadi objek penelitian ini adalah Gender Diversity Dewan, Ukuran Dewan Komisaris, Komisaris Independen, Komite Audit, Konsentrasi Kepemilikan, dan Agresivitas Pajak.

Berikut adalah definisi dan pengukuran variabel. Pada penelitian ini untuk variabel gender diversity berfokus pada komposisi wanita dalam dewan direksi dan komisaris. Menurut Ambarsari, Pratomo, \& Kurnia (2019) Pengukuran gender diversity dewan ini dapat menggunakan rumus berikut:

$$
\text { Gender Diversity Dewan }=\frac{\text { Jumlah perempuan dalam dewan }}{\text { Total anggota dewan direksi dan komisaris }}
$$

Penelitian ini merujuk pada penelitian Arismajayanti \& Jati (2017) yang mengukur komisaris independen dengan menggunakan proporsi komisaris independen dalam dewan komisaris. Jumlah komisaris independen dapat dilihat di 
Jurnal Akuntansi Berkelanjutan Indonesia - Vol. 4, No. 2, Mei 2021 - Kamul \& Riswandari

annual report maupun di laporan keuangan perusahaan. Berikut rumus yang digunakan:

$$
\text { Komisaris Independen }=\frac{\text { Jumlah komisaris independen dalam dewan komisaris }}{\text { Jumlah seluruh komisaris }}
$$

Menurut penelitian Ambarsari, Pratomo, \& Kurnia (2019); Ratnawati, Wahyunir, \& Abduh (2019); Inge Andhitya Rahmawati (2017) ukuran dewan komisaris dapat diukur dengan jumlah dari seluruh anggota dewan komisaris baik independen maupun tidak. Total anggota dewan dapat dilihat dalam laporan tahunan ataupun laporan keuangan perusahaan.

\section{Ukuran dewan komisaris $=$ Jumlah seluruh anggota dewan komisaris}

Menurut Sri Ayem (2019) dan Ratnawati, Wahyunir, \& Abduh (2019) komite audit diukur melalui jumlah seluruh anggota komite audit. Jumlah komite audit bisa dilihat dalam laporan tahunan maupun laporan keuangan perusahaan. Berikut rumus yang digunakan:

\section{Komite Audit = Jumlah seluruh anggota komite audit}

Pada penelitian ini, konsentrasi kepemilikan merupakan jumlah kepemilikan saham terbesar dalam suatu perusahaan dibandingkan dengan jumlah saham yang beredar. Makin tinggi konsentrasi kepemilikan, maka makin terkonsentrasi kepemilikan perusahaan tersebut. Menurut Pratiwi \& Ardiyanto (2018), berikut rumus untuk konsentrasi kepemilikan:

$$
\text { Konsentrasi kepemilikan }=\frac{\text { Kepemilikan saham terbesar }}{\text { Jumlah saham beredar }}
$$

Dalam mengukur agresivitas pajak, peneliti menerapkan proksi Effective Tax Rate (ETR). Halioui et. al. (2008) dalam Rosidy \& Nugroho (2019) menyatakan bahwa pengukuran agresivitas pajak menggunakan ETR di mana paling banyak digunakan dalam beberapa penelitian terdahulu. Semakin rendah nilai ETR artinya semakin kecil perusahaan dalam membayar pajak, artinya perencanaan pajak atau agresivitas pajak semakin tinggi. Semakin tinggi ETR artinya semakin besar jumlah pajak yang dibayar perusahaan, artinya perencanaan pajak atau agresivitas pajaknya semakin rendah. Berdasarkan Ambarsari, Pratomo, \& Kurnia (2019) berikut rumus yang digunakan:

$$
\text { Effective Tax Rate }(\mathrm{ETR})=\frac{\text { Income Tax Expense }}{\text { Pre tax income }}
$$

Populasi dari penelitian ini ialah seluruh perusahaan manufaktur sub sektor consumer goods yang terdaftar di Bursa Efek Indonesia (BEI) tahun 2017-2019. Pemilihan sampel pada penelitian ini dilakukan dengan metode purposive sampling (kriteria yang diinginkan) Kriteria sampel dalam penelitian ini adalah sebagai berikut: 
Jurnal Akuntansi Berkelanjutan Indonesia - Vol. 4, No. 2, Mei 2021 - Kamul \& Riswandari

1. Perusahaan manufaktur sub sektor consumer goods yang secara konsisten terdaftar (listing) di Bursa Efek Indonesia (BEI) dari tahun 2017-2019.

2. Perusahaan manufaktur sub sektor consumer goods yang secara lengkap mempublikasikan informasi annual report dan laporan keuangan dalam periode penelitian 2017-2019.

3. Perusahaan manufaktur sub sektor consumer goods yang menggunakan mata uang rupiah dalam pelaporan keuangannya.

4. Perusahaan manufaktur sub sektor consumer goods yang tidak mengalami kerugian selama periode 2017- 2019.

5. Perusahaan manufaktur sub sektor consumer goods yang memiliki akhir tahun buku 31 Desember.

6. Perusahaan manufaktur sub sektor consumer goods yang memiliki beban pajak penghasilan dalam periode penelitian dan memiliki data-data yang diperlukan dalam penelitian secara lengkap.

Pengujian yang dilakukan dimulai dengan analisis statistik deskriptif, lalu uji asumsi klasik untuk menguji kelayakan data yang terbagi menjadi uji normalitas, heterokedastisitas, multikolinearitas dan uji autokorelasi. Jika sudah memenuhi seluruh uji asumsi klasik maka dilanjutkan uji regresi berganda. Terakhir, dilakukan uji hipotesis yang terdiri dari uji f, uji t dan uji koefisien determinasi. Variabel independen dalam penelitian ini terdiri dari gender diversity dewan direksi, ukuran dewan komisaris, komisaris independen, komite audit dan konsentrasi kepemilikan. Sedangkan agresivitas pajak sebagai variabel dependen yang diproksikan dengan Effective Tax Rate (ETR).

Peneliti menggunakan persamaan regresi sebagai berikut:

$E T R=\alpha+\beta 1 . \mathrm{GNDR}+\beta 2 . \mathrm{SIZEKOM}+\beta 3 . \mathrm{KI}+\beta 4 . \mathrm{KA}+\beta 5 . \mathrm{CONC}+\varepsilon$

Keterangan:

$\mathrm{ETR}=$ Effective Tax Rate

$\alpha=$ Konstanta

$\beta 1=$ Koefisien regresi pertama, yaitu besarnya perubahan $Y$ apabila $X_{1}$ berubah sebesar 1 satuan.

GNDR $=$ Gender diversity Dewan

$\beta 2$ = Koefisien regresi kedua, yaitu besarnya perubahan $\mathrm{Y}$ apabila $\mathrm{X}_{2}$ berubah sebesar 1 satuan.

SIZEKOM = Ukuran Dewan Komisaris

$\beta 3=$ Koefisien regresi ketiga, yaitu besarnya perubahan $\mathrm{Y}$ apabila $\mathrm{X}_{3}$ berubah sebesar 1 satuan

$\mathrm{KI}=$ Komisaris Independen

$\mathrm{B} 4=$ Koefisien regresi keempat, yaitu besarnya perubahan $\mathrm{Y}$ apabila $\mathrm{X}_{4}$ berubah sebesar 1 satuan.

$\mathrm{KA}=$ Komite Audit

B5 = Koefisien regresi kelima, yaitu besarnya perubahan Y apabila X5 berubah sebesar 1 satuan.

$\mathrm{CONC}=$ Konsentrasi Kepemilikan

$\varepsilon=$ Error

* Corresponding author's e-mail: eriswandari@bundamulia.ac.id 


\section{ANALISIS DATA DAN PEMBAHASAN}

Setelah melakukan pemilihan sampel dengan metode purposive sampling berikut merupakan hasil sampel akhir disajikan pada tabel 1:

Tabel 1. Proses Pemilihan Sampel

\begin{tabular}{|c|c|c|c|}
\hline No. & Keterangan & $\begin{array}{l}\text { Jumlah } \\
\text { Perusahaan }\end{array}$ & Jumlah data \\
\hline 1. & $\begin{array}{l}\text { Perusahaan manufaktur sub sektor consumer } \\
\text { goods yang terdaftar di BEI dari tahun } 2017 \\
\text { sampai } 2019\end{array}$ & 47 & 141 \\
\hline 2. & $\begin{array}{l}\text { Perusahaan manufaktur sub sektor consumer } \\
\text { goods yang tidak mempublikasikan laporan } \\
\text { keuangan secara lengkap selama periode } \\
\text { pengamatan }\end{array}$ & (1) & (3) \\
\hline 3. & $\begin{array}{l}\text { Perusahaan manufaktur sub sektor consumer } \\
\text { goods yang tidak menggunakan Rupiah dalam } \\
\text { pelaporan keuangan }\end{array}$ & $(0)$ & $(0)$ \\
\hline 4. & $\begin{array}{l}\text { Perusahaan manufaktur sub sektor consumer } \\
\text { goods yang mengalami kerugian selama periode } \\
\text { pengamatan }\end{array}$ & (13) & $(39)$ \\
\hline 5. & $\begin{array}{l}\text { Perusahaan manufaktur sub sektor consumer } \\
\text { goods yang tidak memiliki akhir tahun buku } 31 \\
\text { Desember }\end{array}$ & $(0)$ & $(0)$ \\
\hline \multirow[t]{4}{*}{6.} & $\begin{array}{l}\text { Perusahaan manufaktur sub sektor consumer } \\
\text { goods memiliki seluruh data yang dibutuhkan } \\
\text { untuk pengamatan }\end{array}$ & $(0)$ & $(0)$ \\
\hline & Jumlah sampel terpilih & 33 & 99 \\
\hline & Data yang bersifat outlier & & $(16)$ \\
\hline & Total data yang diolah & & 83 \\
\hline
\end{tabular}

Berdasarkan kriteria pemilihan sampel yang ditetapkan, sampel yang diperoleh berjumlah 33 perusahaan dalam periode penelitian 3 tahun sehingga jika dikalikan menjadi 99 data namun dikurangi dengan 16 data yang bersifat outlier sehingga jumlah data sampel menjadi 83. Berikut hasil pengujian statistik deskriptif yang mendeskripsikan nilai minimum, maksimum, rata-rata dan standar deviasi dari masing-masing variabel independen dan dependen pada tabel 2:

Tabel 2 Hasil Uji Statistik Deskriptif

\begin{tabular}{llllll}
\hline & $\mathrm{N}$ & Minimum & Maximum & Mean & Std. Deviation \\
\hline GNDR & 83 & .0000 & .6000 & .166740 & .1448232 \\
KI & 83 & .3333 & .8000 & .420438 & .1046938 \\
KA & 83 & 3.0000 & 4.0000 & 3.060241 & .2393792 \\
CONC & 83 & .1019 & .9250 & .631355 & .2418232 \\
SIZEKOM & 83 & 2.0000 & 8.0000 & 4.301205 & 1.5674660 \\
ETR & 83 & .1952 & .3282 & .252855 & .0216992 \\
Valid N (listwise) & 83 & & & & \\
\hline
\end{tabular}

Sumber: Data olahan di SPSS 26

* Corresponding author's e-mail: eriswandari@bundamulia.ac.id http://openjournal.unpam.ac.id/index.php/JABI 
Jurnal Akuntansi Berkelanjutan Indonesia - Vol. 4, No. 2, Mei 2021 - Kamul \& Riswandari

Kemudian dilakukan uji asumsi klasik yang menunjukkan bahwa data layak dan siap diolah. Uji normalitas dilakukan dengan uji one-sample Kolmogorov-Smirnov dengan syarat jika nilai Asymp sig.(2-tailed) lebih dari 0,05 artinya data bersifat normal. Berikut hasil uji normalitas disajikan pada tabel 3.

\section{Tabel 3 Hasil Uji Normalitas}

\begin{tabular}{lll}
\multicolumn{3}{c}{ One-Sample Kolmogorov-Smirnov Test } \\
\hline $\mathrm{N}$ & $\begin{array}{l}\text { Unstandardized } \\
\text { Residual }\end{array}$ \\
Normal Parameters ${ }^{\mathrm{a}, \mathrm{b}}$ & $\begin{array}{l}\text { Mean } \\
\text { Most Extreme Differences }\end{array}$ & .0000000 \\
& Std. Deviation & .01894479 \\
& Absolute & .072 \\
& Positive & .072 \\
Test Statistic & Negative & -.043 \\
Asymp. Sig. (2-tailed) & .072 \\
a. Test distribution is Normal. & $.200^{\text {c,d }}$ \\
b. Calculated from data. & \\
c. Lilliefors Significance Correction. \\
d. This is a lower bound of the true significance. \\
Sumber: Data olahan di SPSS 26
\end{tabular}

Uji multikolinearitas dilakukan untuk menguji apakah terdapat korelasi antara variabel bebas (independen) dalam suatu model regresi. Jika tidak terjadi korelasi antara variabel bebas artinya model regresi sudah baik. Pada tabel 4 disajikan hasil uji multikolinearitas.

Tabel 4 Hasil Uji Multikolinearitas

\begin{tabular}{llll}
\multicolumn{4}{c}{ Coeficients $^{\mathbf{a}}$} \\
\hline Model & & \multicolumn{2}{c}{ Collinearity } \\
Tolerance & Statistics \\
& & & \\
\hline 1 & (Constant) & & \\
& GNDR & .891 & 1.122 \\
& KI & .812 & 1.231 \\
& KA & .968 & 1.033 \\
& CONC & .936 & 1.069 \\
& SIZEKOM & .865 & 1.156 \\
\hline
\end{tabular}

a. Dependent Variable: ETR

Sumber: Data olahan di SPSS 26

Berdasarkan hasil uji di atas dapat diketahui nilai Tolerance keempat variabel lebih dari 0,1 dan VIF keempat variabel kurang dari 10. Maka dapat disimpulkan bahwa tidak terjadi multikolinearitas antar variabel independen dalam penelitian ini.

Uji heterokedastisitas dalam penelitian ini dilakukan dengan menggunakan Scatterplot. Berikut hasil dari uji heterokedastisitas dapat dilihat pada gambar 1 .

* Corresponding author's e-mail: eriswandari@bundamulia.ac.id http://openjournal.unpam.ac.id/index.php/JABI 


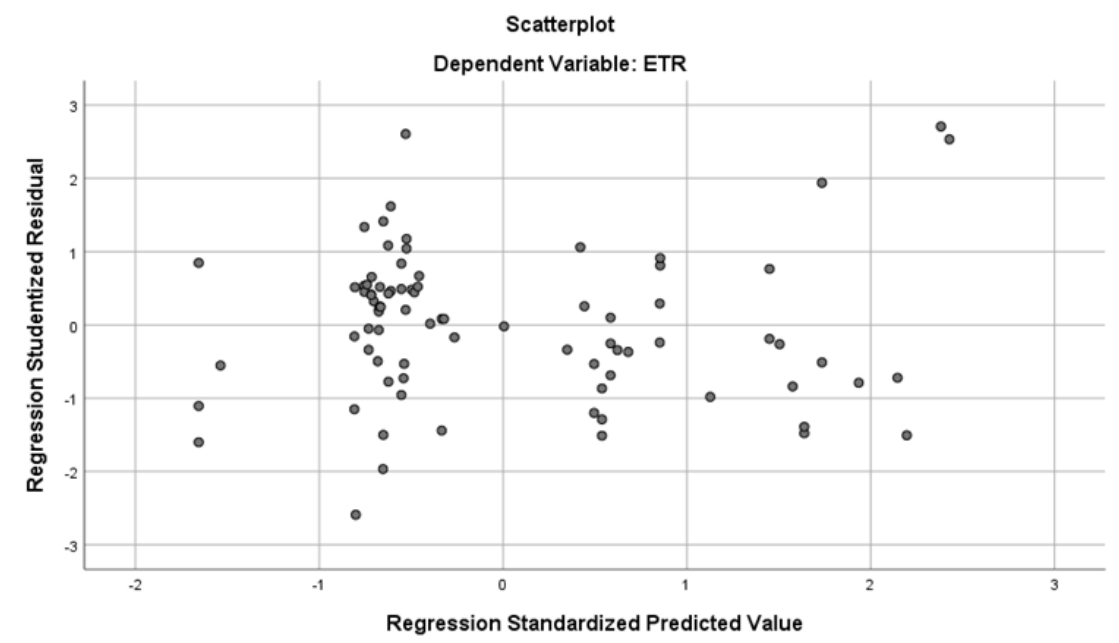

Sumber: Data olahan di SPSS 26

\section{Gambar 1 Hasil Uji Heterokedastisitas}

Berdasarkan gambar di atas terlihat penyebaran titik-titik secara acak dan tidak membentuk pola tertentu serta menyebar rata di atas maupun di bawah angka 0 pada sumbu Y. Oleh karena itu, peneliti menarik kesimpulan bahwa tidak terjadi heterokedastisitas dalam model regresi.

Selanjutnya uji autokorelasi dilakukan dengan run test dengan hasil pada tabel 5 berikut:

\section{Tabel 5 Hasil Uji Autokorelasi}

\section{Runs Test}

\begin{tabular}{ll}
\hline & $\begin{array}{l}\text { Unstandardized } \\
\text { Residual }\end{array}$ \\
\hline Test Value $^{\mathrm{a}}$ & .00156 \\
Cases < Test Value & 41 \\
Cases $>=$ Test Value & 42 \\
Total Cases & 83 \\
Number of Runs & 38 \\
Z & -.993 \\
Asymp. Sig. (2-tailed) & .321 \\
\hline
\end{tabular}

\section{a. Median}

Sumber: Data olahan di SPSS 26

Hasil SPSS dari uji Run Test menunjukkan bahwa nilai test adalah 0,00156 dengan probabilitas 0,321 yang dapat dilihat pada tabel 5 terlihat nilai Asymp. Sig.(2tailed) lebih besar dari 0,05 signifikansi. Hal tersebut menunjukkan bahwa tidak terjadi autokorelasi atau nilai residual bersifat random atau acak.

Hasil dari pengujian regresi linier berganda terdapat dalam tabel 6 . 
Jurnal Akuntansi Berkelanjutan Indonesia - Vol. 4, No. 2, Mei 2021 - Kamul \& Riswandari

Tabel 6 Hasil Uji Regresi Berganda

\begin{tabular}{|c|c|c|c|c|}
\hline \multicolumn{5}{|c|}{ Coefficients $^{\mathrm{a}}$} \\
\hline \multirow{2}{*}{\multicolumn{2}{|c|}{ Model }} & \multicolumn{2}{|c|}{ Unstandardized Coefficients } & \multirow{2}{*}{$\begin{array}{l}\text { Standardized Coefficients } \\
\text { Beta }\end{array}$} \\
\hline & & B & Std. Error & \\
\hline \multirow[t]{6}{*}{1} & (Constant) & .196 & .029 & \\
\hline & GNDR & -.009 & .016 & -.058 \\
\hline & SIZEKOM & .006 & .001 & .462 \\
\hline & KI & -.026 & .023 & -.126 \\
\hline & KA & .014 & .009 & .156 \\
\hline & CONC & -.002 & .009 & -.022 \\
\hline
\end{tabular}

a. Dependent Variable: ETR

Sumber: Data olahan di SPSS 26

Dari tabel 6 dapat dibuat persamaan regresi sebagai berikut:

$\mathrm{ETR}=0,196-0,009 \mathrm{GNDR}+0,006 \mathrm{SIZEKOM}-0,026 \mathrm{KI}+0,014 \mathrm{KA}-0,002 \mathrm{CONC}$ $+\varepsilon$

Koefisien determinasi dalam penelitian ini didasarkan pada Adjusted $R$ Square. Hasil uji koefisien determinasi dapat dilihat dalam tabel 7.

\section{Tabel 7 Hasil Uji Koefisien Determinasi}

\begin{tabular}{|c|c|c|c|c|}
\hline \multicolumn{5}{|c|}{ Model Summary $^{\mathbf{b}}$} \\
\hline Model & $\mathrm{R}$ & $\begin{array}{l}\mathrm{R} \\
\text { Square }\end{array}$ & Adjusted R Square & Std. Error of the Estimate \\
\hline 1 & $.488^{\mathrm{a}}$ & .238 & .188 & .0195502 \\
\hline
\end{tabular}

Menurut tabel 7 diketahui bahwa nilai Adjusted R Square adalah 0,188. Hal ini berarti bahwa variabel-variabel independen yang digunakan dalam penelitian ini, yaitu gender diversity dewan, ukuran dewan komisaris, komisaris independen, komite audit, konsentrasi kepemilikan perusahaan dapat menjelaskan variabel dependen yaitu agresivitas pajak sebesar $18,8 \%$. Sedangkan nilai sisanya $81,2 \%$ lainnya dijelaskan oleh variabel yang tidak diteliti dalam penelitian ini

Tabel 8 Hasil Uji F

ANOVA

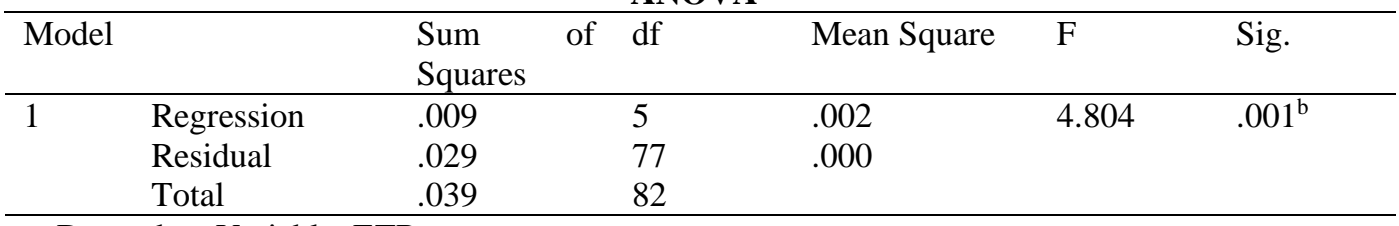

a. Dependent Variable: ETR

b. Predictors: (Constant), SIZEKOM, GNDR, CONC, KA, KI

Sumber: Data olahan di SPSS 26

Menurut tabel 8, dapat dilihat hasil dari uji kelayakan seluruh sampel dan dapat disimpulkan bahwa model regresi dalam penelitian telah cocok (fit) dengan data

* Corresponding author's e-mail: eriswandari@bundamulia.ac.id http://openjournal.unpam.ac.id/index.php/JABI 
dan layak digunakan untuk penelitian ini untuk dilanjutkan ke uji hipotesis karena nilai Sig. nya lebih kecil dari tingkat signifikansi yang ditetapkan sebesar 0,05 dan nilai $F$ hitung (4.804) lebih besar daripada $F$ tabel dengan df $1=5$ dan df2 $=83-5-1=$ 77 yaitu 2,33. Uji F ini juga menunjukkan bahwa seluruh variabel independen yaitu gender diversity dewan, ukuran dewan komisaris, komisaris independen, komite audit dan konsentrasi kepemilikan secara simultan berpengaruh terhadap agresivitas pajak.

Tabel 9 Hasil Uji T

\begin{tabular}{|c|c|c|c|c|c|c|}
\hline \multicolumn{7}{|c|}{ Coefficients ${ }^{\mathrm{a}}$} \\
\hline \multicolumn{2}{|c|}{ Model } & \multirow{2}{*}{\multicolumn{2}{|c|}{$\begin{array}{l}\text { Unstandardized } \\
\text { Coefficients }\end{array}$}} & \multirow{3}{*}{$\begin{array}{l}\text { Standardized } \\
\text { Coefficients } \\
\text { Beta }\end{array}$} & \multirow[t]{3}{*}{$\mathrm{t}$} & \multirow[t]{3}{*}{ Sig. } \\
\hline & & & & & & \\
\hline & & $\mathrm{B}$ & $\begin{array}{l}\text { Std. } \\
\text { Error }\end{array}$ & & & \\
\hline \multirow[t]{6}{*}{1} & (Constant) & .196 & .029 & & 6.843 & .000 \\
\hline & GNDR & -.009 & .016 & -.058 & -.549 & .584 \\
\hline & SIZEKOM & .006 & .001 & .462 & 4.319 & .000 \\
\hline & $\mathrm{KI}$ & -.026 & .023 & -.126 & -1.141 & .257 \\
\hline & KA & .014 & .009 & .156 & 1.543 & .127 \\
\hline & CONC & -.002 & .009 & -.022 & -.211 & .834 \\
\hline
\end{tabular}

a. Dependent Variable: ETR

Sumber: Data olahan di SPSS 26

Berdasarkan hasil pengolahan data dengan SPSS di atas maka dapat diperoleh kesimpulan sebagai berikut:

\section{Pengaruh Gender Diversity Dewan terhadap Agresivitas Pajak}

Berdasarkan hasil uji-t diperoleh nilai signifikansi variabel gender diversity dewan sebesar 0,584 >0,05. Artinya bahwa gender diversity dewan tidak berpengaruh signifikan terhadap agresivitas pajak sehingga Hipotesis pertama ditolak.

Hasil penelitian ini sesuai dengan penelitian Khoula dan Ali (2012) dalam penelitian Ambarsari, Pratomo, \& Kurnia (2019) yang menjelaskan bahwa gender diversity tidak berpengaruh pada Effective Tax Rate karena persentase wanita yang tergolong lebih rendah dibandingkan persentase pria. Penelitian dari Yuwono (2019) diversifikasi dari gender tidak mempengaruhi agresivitas pajak. Penelitian Firdaus Hariyanto (2018) dan Oyenike, Olaynika, Emeni, \& Francis (2016) juga menemukan bahwa keragaman gender dari dewan direksi tidak berpengaruh terhadap agresivitas pajak. Dalam hal ini terjadi perbedaan dengan hipotesis peneliti yang diakibatkan oleh adanya perbedaan di mana pada penelitian yang menjadi rujukan peneliti dilakukan di luar negeri yaitu Australia (Richardson, Taylor, \& Lanis, 2016) diduga karena pada negara tersebut sudah cukup banyak peran wanita dalam dewan. Hal ini juga sesuai dengan grand theory peneliti yaitu teori gender yang menyebutkan bahwa realitasnya laki-laki dan perempuan masih belum sepenuhnya sama. Sedangkan perbedaan dengan penelitian Ambarsari, Pratomo, \& Kurnia (2019) diduga karena perbedaan sektor sampel yang diteliti.

Gender diversity tidak mempengaruhi agresivitas pajak pada sampel yang digunakan peneliti diduga karena di Indonesia khususnya pada perusahaan sampel

* Corresponding author's e-mail: eriswandari@bundamulia.ac.id 
masih sangat sedikit komposisi anggota dewan wanita. Akibat masih kurangnya eksistensi dari anggota dewan wanita, pengambilan keputusan terkait perpajakan juga tidak berdampak besar dengan adanya anggota dewan wanita. Namun meskipun tidak berpengaruh, arah yang terlihat pada hasil adalah positif terhadap agresivitas pajak. Peneliti menduga hal tersebut dikarenakan wanita yang cenderung mengutamakan perasaan daripada pikiran. Sehingga ketika mereka ingin melakukan perencanaan pajak, mereka bisa lebih mudah dipengaruhi oleh lingkungan sekitar yang menuntut mereka untuk melakukan hal tersebut.

\section{Pengaruh Ukuran Dewan Komisaris terhadap Agresivitas Pajak}

Hasil uji-t menunjukkan nilai signifikansi dari variabel ukuran dewan komisaris adalah $0,000<0,05$. Artinya ukuran dewan komisaris berpengaruh signifikan terhadap agresivitas pajak. Maka hipotesis kedua diterima. Dengan koefisien regresi bernilai 0,006 (positif) terhadap ETR berarti berpengaruh negatif terhadap agresivitas pajak yaitu semakin banyak jumlah anggota dewan komisaris maka semakin rendah tingkat agresivitas pajak (semakin tinggi ETR).

Hasil penelitian ini sesuai dengan penelitian Ratnawati, Wahyunir, \& Abduh (2019) yang menemukan hal yang sama bahwa ukuran dewan komisaris berpengaruh negatif terhadap agresivitas pajak secara signifikan. Penelitian Peter Rawlings Osebe (2019) juga menemukan adanya pengaruh positif dari ukuran dewan dengan Effective Tax Rate yang di mana dijelaskan juga bahwa semakin besar ukuran dewan sebagai perwakilan pemegang saham dapat menghalangi tindakan manajer untuk melakukan aktivitas khususnya perencanaan pajak. Hasil penelitian tidak sejalan dengan penelitian Ambarsari, Pratomo, \& Kurnia (2019) diduga karena sampel yang berasal dari beda sektor di mana pada penelitian itu menggunakan sampel perusahaan property dan real estate sedangkan peneliti menggunakan sampel perusahaan consumer goods.

Peran dewan komisaris yang sangat kuat menyebabkan pengawasan yang ketat karena dewan komisaris sebagai perwakilan dari para pemegang saham mengharapkan bahwa laba yang disajikan di laporan keuangan sudah benar dan sesuai. Jika dikaitkan dengan teori agensi yaitu adanya perbedaan kepentingan antara pemegang saham dan manajemen, maka dapat dilihat bahwa pemegang saham dengan perwakilannya yaitu komisaris ingin perusahaan menyajikan laba dengan benar dan tidak ada kecurangan, sementara manajemen ingin membayar pajak sekecil mungkin sehingga merencanakan pajak agar nilainya sekecil mungkin baik dengan cara legal (tax avoidance) maupun ilegal (tax evasion).

\section{Pengaruh Komisaris Independen terhadap Agresivitas Pajak}

Menurut hasil uji-t, nilai signifikansi dari variabel komisaris independen adalah 0,257 >0,05. Artinya komisaris independen tidak berpengaruh signifikan terhadap agresivitas pajak sehingga Ho3 diterima dan Ha3 ditolak. Menurut penelitian dari Arismajayanti \& Jati (2017) dan Dhamara \& Violita (2018), komisaris independen tidak memiliki pengaruh signifikan terhadap agresivitas pajak. Pada penelitian Arismajayanti \& Jati (2017) penelitian dilakukan juga pada sampel perusahaan sektor manufaktur pada periode 2013-2016 dan penelitian Dhamara \& Violita (2018) dilakukan pada sampel perusahaan manufaktur juga 
pada periode 2010-2013. Dapat dilihat bahwa dalam periode yang berbeda pun komisaris independen tidak memiliki pengaruh terhadap agresivitas pajak. Hasil penelitian ini tidak sejalan dengan penelitian Rosidy \& Nugroho (2019) dan Fadli (2016) diduga karena perbedaan proksi pengukuran dari agresivitas pajak di mana pada kedua penelitian itu menggunakan CETR (Cash Effective Tax Rate) sedangkan peneliti menggunakan ETR (Effective Tax Rate).

Komisaris independen dalam suatu perusahaan tidak mempengaruhi agresivitas pajak diduga karena indikasi bahwa komisaris independen tidak melakukan pengawasan yang tepat pada manajemen. Aturan terkait komisaris independen yang mengharuskan paling sedikit 30\% dari semua anggota dewan komisaris hanya dilakukan perusahaan dalam rangka mematuhi peraturan yang berlaku. Corporate governance di Indonesia hanya dipandang sebagai bentuk peraturan dan tidak dipandang kepentingannya. Perusahaan lebih mengarah pada mematuhi peraturan ketimbang memiliki corporate governance yang baik. Corporate governance yang baik tidak menjamin praktek manajemen yang lebih baik dan pengawasan terkait pengambilan keputusan pajak yang lebih baik.

\section{Pengaruh Komite Audit terhadap Agresivitas Pajak}

Hasil uji-t menunjukkan nilai signifikansi komite audit sebesar 0,127>0,05 yang artinya bahwa komite audit tidak berpengaruh terhadap agresivitas pajak. Maka hasilnya Ho4 diterima dan Ha4 ditolak. Maka dapat disimpulkan bahwa komite audit tidak berpengaruh signifikan terhadap agresivitas pajak.

Hal tersebut tidak sesuai dengan perumusan hipotesis peneliti yaitu adanya pengaruh dari komite audit terhadap agresivitas pajak. Hal tersebut kemungkinan dikarenakan pada sampel peneliti kurang banyak variasi dari anggota komite audit yang di mana mayoritas 3 orang yaitu sesuai peraturan pemerintah terkait kewajiban anggota komite audit minimal 3 orang. Hasil penelitian ini juga sejalan dengan penelitian yang dilakukan Ratnawati (2019) yang menemukan tidak adanya pengaruh dari jumlah komite audit yang semakin banyak terhadap agresivitas pajak. Menurut Eksandy (2017) juga menemukan tidak adanya pengaruh dari komite audit dengan penghindaran pajak. Berbeda dengan penelitian Sri Ayem (2019) pada referensi perumusan hipotesis peneliti, kemungkinan dikarenakan ia meneliti perusahaan perbankan yang memiliki variasi jumlah komite audit dan kemungkinan sektor perbankan butuh pengawasan lebih ketat. Sedangkan perbedaan dengan penelitian Setu Setyawan (2019) yang sama-sama meneliti perusahaan manufaktur diduga karena perbedaan cara pengukuran di mana penelitian itu menggunakan CETR dan peneliti menggunakan ETR.

Jika dikaitkan dengan teori agensi, pemerintah selaku principal menetapkan aturan komite audit minimal 3 orang dengan tujuan agar pengawasan dalam perusahaan lebih efektif namun ternyata pada faktanya adanya perbedaan kepentingan antara manajemen selaku agen dan pemerintah selaku prinsipal. Manajemen mengangkat 3 anggota komite audit hanya dalam rangka mematuhi peraturan saja. Manajemen tidak memandang pentingnya aturan terkait tata kelola perusahaan. Maka dari itu di perusahaan yang diteliti juga belum ada pengaruh atau hubungan antara komite audit dengan agresivitas pajak. 


\section{Pengaruh Konsentrasi Kepemilikan terhadap Agresivitas Pajak}

Menurut uji-t yang telah dilakukan, nilai signifikansi dari variabel konsentrasi kepemilikan adalah 0,834>0,05 yang artinya bahwa konsentrasi kepemilikan tidak berpengaruh terhadap agresivitas pajak. Maka dari itu Ho5 diterima dan Ha5 ditolak.

Hasil penelitian tersebut sejalan dengan penelitian Meita Fahrani (2018) yang juga memperoleh hasil bahwa konsentrasi kepemilikan tidak berpengaruh pada agresivitas pajak. Hipotesis peneliti ditolak dan hasil penelitian tidak sesuai dengan penelitian referensi dalam perumusan hipotesis, hal ini diduga karena para pemegang saham cenderung mempercayakan pada manajerial untuk mengelola perusahaan agar laba perusahaan terus meningkat. Pihak manajemen perusahaan tentu lebih mengetahui kinerja perusahaan dibanding pemegang saham sehingga tindakan agresivitas pajak sepenuhnya dilakukan oleh internal perusahaan atau manajerial sehingga pemegang saham mayoritas tidak ikut serta terkait hal tersebut. Pemegang saham mayoritas akan puas selama laba yang diperoleh perusahaan tinggi. Selain itu, penyebab terjadinya perbedaan hasil juga kemungkinan karena pada penelitian acuan perumusan hipotesis dilakukan di negara lain seperti China (Ying, Wright, \& Huang, 2017) dan Nigeria (Ogbeide \& Obaretin, 2018). Kemungkinan besar di negara tersebut pemilik saham terbesar memegang peran penting dalam pengambilan keputusan terkait perpajakan.

\section{KESIMPULAN DAN SARAN}

Kesimpulan penelitian ini adalah Gender Diversity, Komite Audit, Komisaris Independen, dan Konsentrasi Kepemilikan tidak berpengaruh signifikan terhadap agresivitas pajak. Namun Ukuran Dewan Komisaris berpengaruh signifikan terhadap agresivitas pajak. Keterbatasan penelitian ini adalah beberapa perusahaan pada sektor yang diteliti tidak menyantumkan informasi laporan keuangan dengan lengkap, serta komposisi dewan wanita yang masih sedikit pada sektor yang diteliti. Pengumpulan data juga dilakukan dengan data keuangan sebelum dilakukan restatement. Saran penelitian berikutnya adalah menggunakan proksi yang berbeda untuk variabel yang diteliti serta mengembangkan variabel lain yang diduga mempengaruhi agresivitas pajak.

\section{DAFTAR PUSTAKA}

Ambarsari, D., Pratomo, D., \& Kurnia. (2019). Pengaruh Ukuran Dewan Komisaris, Gender Diversity pada Dewan, dan Kualitas Auditor Eksternal terhadap Agresivitas Pajak. Jurnal Ilmiah Akuntansi, 17(2), 142-157. doi:10.17509/jaset.v10i2.14991

Arismajayanti, N. P., \& Jati, I. K. (2017). Influence of Audit Committee Competence, Audit Commitee Independence, Independent Commisioner and 
Jurnal Akuntansi Berkelanjutan Indonesia - Vol. 4, No. 2, Mei 2021 - Kamul \& Riswandari

Leverage on Tax Aggressiveness. Journal of Auditing, Finance, and Forensic Accounting, 5(2), 109-119. doi:10.21107/jaffa.v5i2.3767

Dhamara, G. P., \& Violita, E. S. (2018). The Influence of Financial Distress and Independence of Board of Commisioners on Tax Aggresiveness. Journal Adcvances in Economics, Business and Management Research IAC 2017, 55, 81-86.

Effendi, M. A. (2016). The Power Of Good Corporate Governance: Teori dan Implementasi (2 ed.). Jakarta: Salemba Empat.

Fadli, I. (2016, Februari). Pengaruh Likuiditas, Leverage, Komisaris Independen, Manajemen Laba, dan Kepemilikan Institusional Terhadap Agresivitas Pajak Perusahaan. JOM Fekon, 3(1), 1205-1219.

Frank, M.M., Lynch, L.J., \& Rego, S.O. (2009). Tax Reporting Aggressiveness and Its Relation to Aggressive Financial Reporting. Social Science Research Network, 84 (2), 467-496

Harjito, Y., Sari, C. N., \& Yulianto. (2017). Tax Aggressiveness Seen From Company Characteristics and Corporate Social Responsibility. Journal of Auditing, Finance, and Forensic Accounting, 5(2), 77-91.

Harnovinsah, \& Mubarakah, S. (2016). Dampak Tax Accounting Choices Terhadap Tax Aggressive. Jurnal Akuntansi, $\quad X X(02), \quad$ 267-284. doi:10.24912/ja.v20i2.58

Meita Fahrani, S. N. (2018). Pengaruh Kepemilikan Terkonsentrasi, Ukuran Perusahaan, Leverage, Capital Intensity, dan Inventory Invensity terhadap Agresivitas Pajak. Jurnal Ekonomi Paradigma, 19(02), 52-60.

Makhfudloh, Herawati dan Wulandari. (2018). Pengaruh Corporate Social Responsibility terhadap Perencanaan Agresivitas Pajak. Jurnal Akuntansi dan Bisnis. Vol.18 No.1. 48-60

Nugraha, Meiranto Bani dan Meiranto Wahyu. (2015). Pengaruh Corporate Social Responsibility, Ukuran Perusahaan, Profitabilitas, Leverage, dan Capital Intensity Terhadap Agresivitas Pajak (Studi Empiris pada Perusahaan Non Keuangan yang Terdaftar di Bursa Efek Indonesia 2012-2013). Diponegoro Journal Of Accounting. Vol. 4, No. 4. ISSN (Online): 2337-3806

Ogbeide, S. O., \& Obaretin, O. (2018). Corporate Governance Mechanism and Tax Aggressiveness of Listed Firms in Nigeria. Amity Journal of Corporate Governance, 3(1), 1-12.

Oktavianna, R., \& Prasetya, E. R. (2021). Analisis Manajemen Laba yang Dipengaruhi oleh Komite Audit dan Firm Size Perusahaan LQ 45 Tahun 2015-2019. Jurnal Ilmiah Akuntansi Universitas Pamulang, 9(1), 54-64.

Oyenike, O., Olayinka, E., Emeni, \& Francis. (2016). Female Directors and Tax Aggressiveness of Banks in Nigeria. 3rd International Conference on African Development Issues, 293-299.

Peter Rawlings Osebe, J. K. (2019). Impact of Corporate Governance on Effective Corporate Tax Rates Among Listed Firms in Kenya. Research Journal of Finance and Accounting, 10(18), 23-33. doi:10.7176/RJFA

Pratiwi, D. A., \& Ardiyanto, M. D. (2018). Pengaruh Struktur Kepemilikan terhadap Agresivitas Pajak. Diponegoro Journal of Accounting, 7(4), 1-13. doi:2337-3806 
Jurnal Akuntansi Berkelanjutan Indonesia - Vol. 4, No. 2, Mei 2021 - Kamul \& Riswandari

Ratnawati, V., Wahyunir, N., \& Abduh, A. (2019). The Effect of Institutional Ownership, Board of Commissioners, Audit Committee on Tax Aggressiveness; Firm Size as Moderating Variable. International Journal of Business \& Economy, 1(2), 104-115. Retrieved from http://myjms.moe.gov.my/index.php/ijbec

Richardson, G., Taylor, G., \& Lanis, R. (2016). Women on the board of directors and corporate tax aggressiveness in Australia. Accounting Research Journal, 29(3), 313-331. doi:10.1108/ARJ-09-2014-0079

RM Oyotode-Adebile, ZA Raja. (2019) Board gender diversity and US corporate bonds . International Journal of Managerial Finance. 625944

Rosidy, D., \& Nugroho, R. (2019). Pengaruh Komisaris Independen dan Kompensasi Eksekutif terhadap Agresivitas Pajak. Jurnal Info Artha, 3(1 ), 55-65. doi:10.31092/jia.v3i1.563

Setu Setyawan, E. D. (2019, Oktober). Kebijakan Keuangan Dan Good Corporate Governance Terhadap Agresivitas Pajak. Jurnal Reviu Akuntansi dan Keuangan, 9(3), 327-342. doi:10.22219/jrak.v9i3.65

Sri Ayem, A. S. (2019). Pengaruh Profitabilitas, Ukuran Perusahaan, Komite Audit Dan Capital IntensityTerhadap Agresivitas Pajak (Studi Pada Perusahaan Perbankan Yang Terdaftar di BEI Periode Tahun 2013-2017). Jurnal Akuntansi Pajak Dewantara, 1(2), 228-241. doi:10.24964/japd.v1i1.905

Utaminingsih, A. (2017). Gender dan Wanita Karir. Malang: UB Press.

Ying, T., Wright, B., \& Huang, W. (2017). Ownership structure and Tax Aggressiveness Of Chinese Listed Companies. International Journal of Accounting \& Information Management, 25(3), 313-332. doi:10.1108/IJAIM-07-2016-0070 